\title{
Analysis of Relevance of Mathematics Curriculum Development
}

\author{
Moh. Mahfud Effendi \\ Mathematics Education Department, \\ University of Muhammadiyah Malang \\ email: effendimahfud4@gmail.com
}

\begin{abstract}
The main purpose of Vocational High School (SMK) is to prepare students to work, but the most unemployment comes from graduates of SMK. This case can occur because the curriculum development does not meet the principle of relevance, both internal and external. Internally, the development of SMK curriculum component must be integrated. While externally, SMK curriculum development must prepare students to be able to live and work. The question is whether the development of a mathematics curriculum in SMK meets the principle of relevance. To answer the research problem, the data collection technique used are document and interview techniques. The document is a mathematics learning plan (MLP) at SMK in Malang, Batu, and Bojonegoro. Data from the documents and interviews are analyzed qualitatively in relation to the principle of relevance. Based on the analysis it is found that: 1) the development of the mathematics curriculum in SMK is not based on the need of the skill program or not integrated; and 2) graduate competence standard (GCS), basic competencies (BC), indicators, objectives, teaching materials, methods, and assessment of mathematics learning outcomes are less compatible. Thus it can be concluded that the mathematics curriculum in SMK does not meet the principle of relevance.
\end{abstract}

Keywords: SMK, math curriculum, and relevance

\section{INTRODUCTION}

The largest unemployment rate in Indonesia until February 2016 comes from SMK graduates [28]. One of the factors is curriculum development and learning. The SMK curriculum should be developed in accordance with the needs of the work, economy, society, and students [1,5,11,16,29]. Therefore, the development of curriculum and learning is to combine professional knowledge with work skills $[3,11,30,32,33]$. Such an effort is effective if the goal of all the lessons is sustained or integrated with the purpose of its program of expertise $[8,19]$. Basically, the integrated curriculum is to make it easier for students to learn the teaching materials and learn meaningfully, so that the goal of the skills program is effective $[1,4,6,11]$.

In addition to the main purpose for work, SMK graduates can also continue to college [31], so that SMK students are required to take the national exam [22,23,31]. This case has an impact on the burden of learning more SMK than SHS students, and the development of mathematics curriculum using supply-driven principles. The impact of curriculum development is the overload and overlap of teaching materials, and less consider the scope and sequence of teaching material deliverables as a whole [6]. If so, then the learning of mathematics in SMK does not focus on the essential mathematical material needed by its skill program, or not integrated $[3,5,6,20]$.

One of the principles of curriculum development is the principle of relevance. This relevance is both internal and external $[20,25]$. Internal relevance is the integrity of the curriculum, which is the integration between the goals to be achieved, the content or the material or the learning experience, the process or the method or strategy, and the means of assessment used to see the achievement of the objectives. While the relevance of an external nature is the preparation of students to be able to work and live in the community. This principle describes that the objectives, teaching materials, learning processes covered in the curriculum should be relevant to the demands, needs, and development of work and society. The question is whether the development of a mathematics curriculum in SMK meets the principle of relevance.

\section{METHOD}

The curriculum is a guideline for the implementation of learning activities to achieve educational goals. These guidelines include setting objectives, content or lesson materials that students should learn, and how to learn them $[24,26]$. Development of SMK mathematics curriculum is the development of mathematics learning guidance in SMK, that is syllabus or MLP. Based on the description and to answer the above problem, this research is qualitative descriptive type with case approach $[2,10,18,27]$.

This research is document research, so the technique of data collection is document technique. The documents analyzed are the MLP, class 10 and 12 in SMK at MGMP Malang, SMK Bina Mandiri Malang, SMK EL Malang, SMKN 2 Batu, and SMKN Temayang Bojonegoro. For data validity, then also use interview technique. The focus of the analysis is the external and internal relevance. Analysis of external relevance is analyzing the compatibility or integration of GCS, $\mathrm{BC}$, indicators, mathematics teaching materials with the purpose of their programming skills. While the internal relevance analysis is to analyze the consistency or conformity between GCS, BC, indicators, teaching materials, methods or approaches, learning resources, and assessment in the MLP.

Analysis of MLP elements using Likert Scale with four cecklist options, namely: very not accordance, not accordance, accordance, and very accordance. The results of this document are analyzed qualitatively and used to describe their relevance. To calculate and analyze it then the data 
transformed into quantitative data in accordance with the score are: 1, 2, 3, and 4 [21]. After the data is transformed into quantitative data, the calculation of the rating scale is by using the percentage $[18,21]$. To determine the relevance level, use the category with the following scale.

Table 1. Category of the relevance level

\begin{tabular}{ccc}
\hline No & Scala $(\%)$ & Category \\
\hline 1. & $0-<25$ & Very Irrelevant (VIR) \\
2. & $25-<50$ & Irrelevant (IR) \\
3. & $50-<75$ & Relevant (R) \\
4. & $75-100$ & Very Relevant (VR) \\
\hline
\end{tabular}

\section{RESULT}

\section{A. External Relevance}

The principle of external relevance means that the objectives, teaching materials, learning processes covered in the mathematics curriculum in SMK must be relevant to the demands, needs, and developments of the objectives of the program. That is, the development of GCS, BC, indicators, and mathematics teaching materials must refer to and integrate with competence standard of program expertise [1,4,6,11]. Therefore, the mathematics teaching materials of each skill program are different. Mathematics learning in SMK with problem solving approach, aimed to enable students to adapt and deal with science and technology changes and work needs through critical, rational, and creative thinking, and can use mathematical mindset in learning other science and work $[13,15]$.

Besides BC and teaching materials are different, MLP format from one skill program to another is also different. This can be clearly seen in the MLP header, which is for what skills program. Based on the identification results of MLP, none of the MLPs include skills programs, and there is even a MLP that reads "for all skills programs". In this case, the objectives, $\mathrm{BC}$, and mathematics teaching materials between one skill programs are the same, which means very irrelevant (Vir) category. This case is certainly contrary to the function, principle, and objectives of mathematics learning in SMK, that is to support the purpose of the program of expertise $[9,20]$. This is, of course, contrary to the function, principle, and objective of mathematics learning in SMK, which is to support the objectives of the program of expertise $[9,20]$. Based on this, it can be said that the mathematics curriculum in SMK does not meet the principle of external relevance.

\section{B. Internal Relevance}

If a curriculum does not meet the principle of external relevance, then the curriculum does not qualify for relevance, because external relevance is an absolute requirement. Based on internal relevance analysis, the conformity between core competences/GCS, BC, indicator, objective, material/student worksheet, method/approach, and asessment, is obtained as the following table.
Table 2. Conformity between core competences/GCS, BC, indicator, objective, material/student worksheet, method/approach, and asessment.

\begin{tabular}{|c|c|c|c|c|c|c|c|c|}
\hline NO & $\begin{array}{l}\text { Aspect of } \\
\text { Relevance }\end{array}$ & A & B & C & D & $\mathrm{E}$ & $\%$ & Category \\
\hline 1 & $\begin{array}{l}\text { BC with core } \\
\text { competences/GCS }\end{array}$ & 3 & 2 & 2 & 3 & 2 & 60 & $\mathrm{R}$ \\
\hline 2 & Indicator with $\mathrm{BC}$ & 3 & 3 & 2 & 3 & 3 & 70 & $\mathrm{R}$ \\
\hline 3 & $\begin{array}{l}\text { Objective with } \\
\text { indicator } \\
\text { Material/student } \\
\text { worksheet with }\end{array}$ & 2 & 2 & 2 & 3 & 2 & 55 & $\mathrm{R}$ \\
\hline 4 & $\begin{array}{l}\text { indicator } \\
\text { method/approach }\end{array}$ & 3 & 2 & 2 & 3 & 3 & 65 & $\mathrm{R}$ \\
\hline 5 & with objective & 3 & 2 & 2 & 2 & 2 & 55 & $\mathrm{R}$ \\
\hline 6 & indicator & 2 & 1 & 1 & 2 & 2 & 40 & IR \\
\hline & Percentage $(\%)$ & 66,7 & 50,0 & 45,8 & 66,7 & 58,3 & 57,5 & $\mathrm{R}$ \\
\hline & Category & $\mathrm{R}$ & $\mathrm{R}$ & IR & $\mathrm{R}$ & $\mathrm{R}$ & $\mathrm{R}$ & \\
\hline
\end{tabular}

$\begin{array}{ll}\text { Note: } & \\ \text { A } & =\text { SMK Malang at MGMP Malang } \\ \text { B } & =\text { SMKN Temayang Bojonegoro } \\ \text { C } & =\text { SMK EL Malang } \\ \text { D } & =\text { SMKN 2 Batu } \\ \text { E } & =\text { SMK Bina Mandiri Malang }\end{array}$

In general, MLP for SMK meets the principle of internal relevance with a score of $57.5 \%$ (category $\mathrm{R}$ ). The smallest percentage is in the appropriateness of the assessment with the indicator of $40 \%$ (IR), while the highest percentage is the conformity of the indicator BC, which is $70 \%$ (category $\mathrm{R}$ ). The low suitability of the assessment with the indicator is due to: 1$)$ the cognitive aspect $(\mathrm{C} 1, \mathrm{C} 2, \mathrm{C} 3$, etc. $)$ is not in accordance with the assessed, and 2) in the indicator there is no affective aspect but the value in the assessment. While the high percentage of conformance indicator with $\mathrm{BC}$, because indicators and $\mathrm{BC}$ is on the syllabus and only copy paste. From 5 sources of the research, only MLP in SMK EL Malang is categorized as irrelevant (IR), because the format of the MLP of the school is still the old RPP format

In Government Regulation as UUSPN No. 20 Ps.3, 2003 and PP N0. 22, 2006 sub. IIC, that the purpose of SMK is to prepare their students to work at the madya level.His orientation is being able to work in accordance with the competencies required by his work. The effectiveness of this goal depends on how the organization of its curriculum. Thus, all the lessons taught in SMK including mathematics must be integrated and support GCS from its expertise program $[1,7,9]$. Therefore, the orientation of learning mathematics must be able to help students to more easily learn and understand the program expertise. This can be achieved if GCS, BC, indicators, and mathematics teaching materials are developed consistently and relevant to the needs of the skills program.

$\mathrm{Lu}$ Hong in his research entitled: Thought and Practice on Curriculum Reform in Higher Vocational Colleges, it is said that the importance of reform in vocational education [17]. Reforms can be interpreted as the development of mathematics teaching materials in accordance with the objectives of the program expertise in SMK. In addition, the 
development of methods and evaluation of learning outcomes should be able to explore and elaborate mathematical concepts to solve skills program problems or the needs of professional positions. The principle of reforming the contents of the mathematics curriculum should be designed, and should focus on important mathematical material and required by its skill program [20]. In relation there with, the re-design of the mathematics curriculum for SMK is the best way in the continuous development of the SMK curriculum. LIU Deen in research "Characteristics of Curriculum in Higher Vocational Education" [5] emphasized that the development of SMK curriculum should have four features, namely: (1) job-oriented in curriculum objectives, (2) appled technology based curriculum content, (3) work activity centered curriculum organization, and (4) curriculum implementation through teaching integrated with operation. These four features should be a foothold in the development of the mathematics curriculum in SMK to meet the principles of relevance both external and internal.

The integrated curriculum must be implemented in the classroom. Integrated learning is a meaningful learning that is very effective in achieving the objectives of learning. That is, if all the lessons in SMK are integrated, that it affects the students' understanding of their skills program [6]. This is in accordance with the research results of Yi-Hsuan GL and Bella OS, in the research of ESP curriculum development in SMK [11]. The results of his research, that the ESP ITB program (Intensive Task-Based English for Special Purposes) has a significant impact on understanding the concepts and skills of SMK students in English-language business presentations. Therefore, the objectives of each subject in the vocational school should be directed to the effectiveness of the achievement of the competency of the program. So far, mathematics learning in SMK is separated from other lessons [6].

\section{CONCLUSION}

The purpose of SMK is to prepare students for work. The learning objectives of all subjects should be relevant and integrated with the objectives of the program's expertise. Therefore, the development of mathematics curriculum must meet the principle of relevance that is the relevance of the external and internal. The number of unemployed SMK graduates, also caused by the development of a mathematics curriculum that does not meet the principle. Based on the results of the analysis, it can be proved that: First, the development of GCS, BC, indicators, mathematics teaching materials in SMK is not based on the needs of the skills program or not integrated. That is, it does not meet the principle of external relevance. Second, the development of GCS, BC, indicators, teaching materials, methods or approaches, learning resources, and assessments in the mathematics lesson in SMK are inconsistent or inappropriate. That is, it does not meet the principle of internal relevance. Thus it can be concluded that the development of mathematics curriculum in SMK does not meet the principle of relevance.

\section{REFERENCES}

[1]. Beane, James A. Curriculum Integration; Designing the core of democratic Education. New York and London: Teachers College Press, (1977).

[2]. Borg WR \& Gall M.P. Educational Research, An Introduction 7th Edition. Pearson Education, Inc, (1977).

[3]. Bowers, Helen. Curriculum Design in Vocational Education. Fully refereed paper for the Australian Association for Research in Education-2006 Conference 26-30 November 2006, Adelaide, (2006).

[4]. Dayuan, Jiang. Thoughts on Fundamental Problems of Vocational Education Pedagogy: Journal Vocational and Technical Education; 2006-04, (2006).

[5]. Deen, LIU. Characteristics of Curriculum in Higher Vocational Education: Journal Vocational and Technical Education; 2001-16, (2001).

[6]. Effendi, Moh Mahfud. Pengembangan Kurikulum Matematika sebagai Mata Pelajaran Adaptif pada Program Keahlian Tata Busana SMKN 3 Probolinggo. Jurnal Penelitian Pendidikan 1412-565X Edisi khusus Februari 2013 hal 43-60, (2013).

[7]. Effendi, Moh Mahfud. Alternatif Model Organisasi Kurikulum Matematika Sekolah Menengah Kejuruan (SMK). Jurnal HIPKIN: Inovasi Kurikulum, ISSN: 1829-6750 Volume 01 Maret 2014; hal 123-135, (2014).

[8]. Fang, LI Ju, and Zheng, ZHOU Jian. The construction and implementation of work-integrated learning "Three Policy" model in the vocational college of mapping class: Journal Science of Surveying and Mapping; 201005, (2010).

[9]. Fogarty. (1991). How to Integrate The Curricula: The Mindful School. Palatine, Illinois: Skylight Publishing, Inc.

[10]. Gay, L.R, et.al,. Educational Research: Competencies for Analysis and Applications. New Jersey: Pearson Prentice Hall, (2006).

[11]. Gloria Lo, Yi-Hsuan and Sanjaya, Bella Oktaviani. When Academia Meets Industry: Effective ESP Curriculum Development for Vocational High School Students Delivering Profesional Business Presentations. English as a Global Language Education (EaGLE) Journal: Vol. 1 No. 2; pag. 31-62, (2015).

[12]. Hamalik. Dasar-Dasar Pengembangan Kurikulum. Bandung: Rosdakarya, (2008).

[13]. Henk vdK,. Mathematics for Technical Vocational Education. Research Intersts and Universities. http://www.academica.edu, (2010).

[14]. Karseth, Berit. Curriculum Restructuring In Higher Education After The Bologna Process: A New Pedagogic Regime This article is a revised version for this monograph of a paper presented at The Third Conference on Knowledge and Politics at the University of Bergen, May 18-20th, 2005. Journal: Revista 
Española de Educación Comparada, 12 (2006), 255-284, (2006).

[15]. Lisbeth L dan Lulea T,. To Look for Mathematics Teaching and Learning in Vocational Education. www.mail.liu.se/SMDF/madif5/Lindberg, (2013).

[16]. Longstreet,W.S. Curriculum for a New Millenium. Boston; Allyn \& Bacon, (1993).

[17]. Lu Hong. Thought and Practice on Curriculum Reform in Higher Vocational Colleges: Journal of Anhui Vocational \& Technical College;2009-01, [CateGory Index]: F830-4;F712.3, (2009).

[18]. McMillan, James H. Educational Research: Fundamentals for The Consumer, 5th Edition USA: Person Education, Inc, (2008).

[19]. McNeil. Contemporary Curriculum in Thought\&Action. USA:John Wiley\& Sons (2006).

[20]. NCTM (National Council of Teachers of Mathematics). Principles and Standards for School Mathematics. USA: The NCTM, Inc, (2000).

[21]. Oppenheim, A.N. Questionare Design and Attitude Measurement. London: Heinemann (1982).

[22]. Peraturan Menteri Pendidikan dan Kebudayaan nomor 70 tahun 2013 Tentang Kerangka Dasar dan Struktur Kurikulum SMK/MAK.

[23]. Peraturan Menteri Pendidikan Dan Kebudayaan Republik Indonesia Nomor 60 Tahun 2014 Tentang Kurikulum 2013 Sekolah Menengah Kejuruan/ Madrasah Aliyah Kejuruan.

[24]. Print, M. Curriculum Development and Design, Australia; Allen\& Unwin Pty Ltd, (1993).

[25]. Sanjaya, W. Kurikulum dan Pembelajaran; Teori dan Praktek Pengembangan KTSP. Jakarta: Kencana Prenada Media Group, (2008).

[26]. Sanjaya, W. Kurikulum dan Pembelajaran; Teori dan Praktek Pengembangan KTSP. Jakarta: Kencana Prenada Media Group, (2008).

[27]. Sugiyono. Metode Penelitian Kuantitatif,Kualitatif,dan R\&D. Bandung; Alfabeta, (2008).

[28]. Suryamin. Angka Pengangguran SMK Tertinggi di Indonesia, BPS Indonesia, (2016).

[29]. Tight, Malcolm. Key Concepts in Adult Education and Training.Second edition. Canada: RoutledgeFalmer, (2002).

[30]. Toth, Peter. Learning Strategies and Styles in Vocational Education. Acta Polytechnica Hungarica: Vol 9, No. 3, 2012, (2012).

[31]. Undang-Undang Sistim Pendidikan Nasional Nomor 20 Tahun 2013.

[32]. Xin, Zhao. Vocational Education Curriculum Development Oriented by Working Process Knowledge: Journal of Anhui Vocational \& Technical College; 2007-07, (2007).

[33]. Yimin, Wang. Exploitation and Practice of Theorypractice Integrated Professional Courses: Journal Vocational and Technical Education; 2006-04, (2006). 